\title{
PERHITUNGAN KURVA HISTERESIS INTRINSIK MATERIAL ZINC OXIDE (ZnO)
}

\author{
Septian Rahmat Adnan ${ }^{1,2}$ dan Bambang Soegijono ${ }^{2}$ \\ ${ }^{1}$ Teknik Industri, Fakultas Teknik, Universitas Esa Unggul \\ ${ }^{2}$ Departemen Fisika, FMIPA, Universitas Indonesia \\ e-mail : septian.rahmat@esaunggul.ac.id
}

\begin{abstract}
ABSTRAK
Energi bebas Gibbs dan kurva polarisasi spontan dari Zinc Oxide (ZnO) dihitung menggunakan Teori LandauDevonshire. Program komputasi untuk menghitung Energi bebas Gibbs dan kurva polarisasi spontan dibuat pada Delphi 6. Dari hasil perhitungan menunjukan bahwa energi bebas Gibbs terendah terdapat pada ZnO doping Li $1 \%$ s yang menunjukan struktur kristal paling stabil.
\end{abstract}

Kata kunci: Landau-Devonshire, ZnO, Ferroelektrik

\section{PENDAHULUAN}

Material Zinc Oxide $(\mathrm{ZnO})$ telah banyak diteliti karena sifatnya yang merupakan semikonduktor dan menjadi material kandidat untuk aplikasi memori dan sensor. (Bornand, 2013). Bornand dan Merzy pada tahun 2013 menemukan bahwa Zinc Oxide $(\mathrm{ZnO})$ dengan doping litium memiliki sifat ferroelektirk yang meningkat dikarenakan atom $\mathrm{Li}^{+}$yang menggantikan atom $\mathrm{Zn}^{2+}$ dan posisi atom $\mathrm{Li}^{+}$ tidak tepat berada di pusat kristal menyebabkan adanya dipol elektrik permanen dan berpengaruh pada sifat ferroelektrisitasnya. Teori Landau-Devonshire telah banyak digunakan peneliti dikarenakan cukup memuaskan untuk menjelaskan sifat ferroelektrisitas suatu material. (Lines dkk, 1977, Hikam dkk, 2014, Tan, 2001)

Pada penelitian ini dilakukan perhitungan konstanta Landau dari Zinc Oxide ( $\mathrm{ZnO})$ Aldrich, eksperimen dan $\mathrm{ZnO}$ doping $\mathrm{Li} 1 \%$. Teori Landau-Devonshire digunakan untuk menggambarkan dan menganalisa energi bebas Gibbs dan kurva polarisasi spontan dari ZnO.

\section{METODE PENELITIAN}

Fenomena sifat intrinsik ferroelektrisitas dari material Zinc Oxide ( $\mathrm{ZnO})$ dapat dihitung energi bebas Gibbsnya dengan menggunakan teori Landau-Devonshire (LD) (Hikam dkk, 2014, Lines dkk, 1977, Tan dkk, 2001):

$F(P, E)=F_{0}+\frac{\alpha\left(T-T_{c}\right)}{2} P^{2}-\frac{\beta}{4} P^{4}+\frac{1}{6} P^{6}-E P$ dimana $\mathrm{T}$ adalah suhu material pada saat dilakukan pengujian, $\mathrm{T}_{\mathrm{c}}$ adalah suhu Currie dari material, $\mathrm{P}$ adalah Polarisasi, E adalah medan listrik yang diterapkan pada material, $\alpha$ dan $\beta$ adalah konstanta Landau. Maka energi bebas Gibbs dapat disederhanakan menjadi :

$F=\frac{\alpha}{2} P^{2}-\frac{\beta}{4} P^{4}+\frac{1}{6} P^{6}-E P$

Dengan menganggap energi bebas Gibbs pada material Zinc Oxide ( $\mathrm{ZnO})$ pada kondisi minimum, maka (Hikam dan Adnan, 2014, Padurariu dkk, 2016) :

$$
\frac{F(P, E)}{d P}=\alpha\left(T-T_{c}\right) P^{2}-\beta P^{3}+P^{5}=0
$$

nilai $\alpha$ dan $\beta$ dapat dihitung dari data eksperimen dengan menggunakan persamaan berikut

$$
\begin{aligned}
& \alpha=\beta P_{s}^{2} \\
& \beta=\frac{3 \sqrt{3} E_{C}}{2 P_{s}^{3}}
\end{aligned}
$$

dengan $\mathrm{P}_{\mathrm{s}}$ adalah polarisasi spontan dan $\mathrm{E}_{\mathrm{c}}$ adalah medan koersif.

Perhitungan energi Bebas Gibbs dan polarisasi spontan dari material Zinc Oxide (ZnO) dilakukan pada program Delphi 6 buatan sendiri. Dengan tahap pertama adalah perhitungan koefisien Landau dengan persaman 4 dan 5 dari masing - masing jenis material, dilanjutkan dengan pembuatan program dengan 
Delphi 6 dan menggunakan koefisien Landau sebagai data masukan untuk perhitungan Energi Bebas Gibbs dan kurva polarisasi spontan dari masing - masing material dengan menggunakan persamaan 2. Selanjutnya dilakukan analisa dari hasil yang didapat. Alur perhitungan Energi bebas Gibbs dan polariasi spontan ditunjukan pada gambar 2.1.

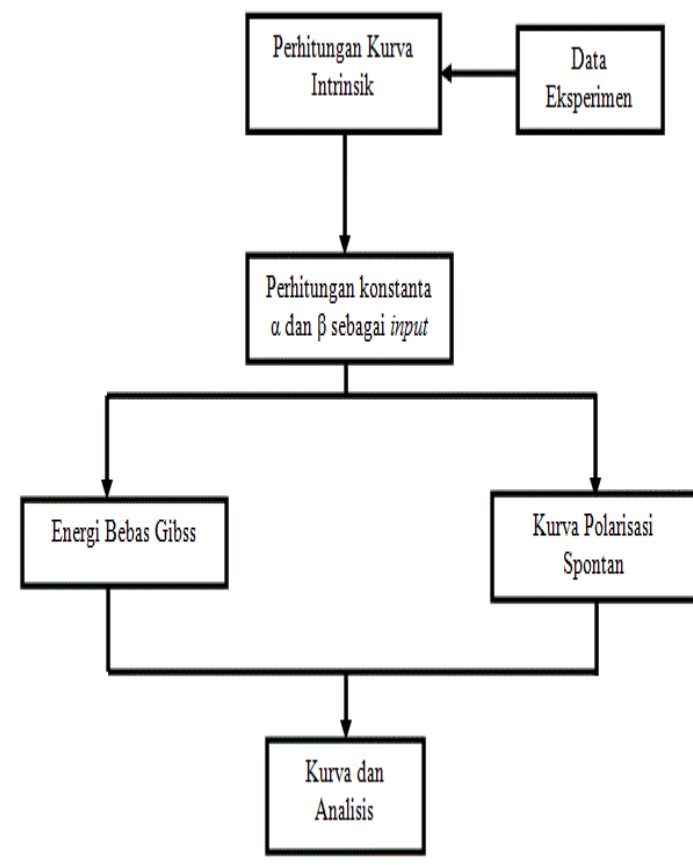

Gambar 2.1. Alur Penelitian

Nilai Polarisasi spontan dan medan koersif dari material Zinc Oxide ( $\mathrm{ZnO})$ diukur menggunakan rangkaian Sawyer-Tower.

\section{HASIL DAN PEMBAHASAN}

Hasil uji sifat ferroelektrisitas dari material $\mathrm{ZnO}$ eksperimen ditunjukan pada gambar 3.1. Dari kura histeresis terlihat bahwa nilai medan koersif dari material $\mathrm{ZnO}$ eksperimen adalah $83 \mathrm{kV} / \mathrm{m}$ dan nilai polarisasi spontan adalah $2.7 \times 10^{-4} \mathrm{C} / \mathrm{m}^{2}$

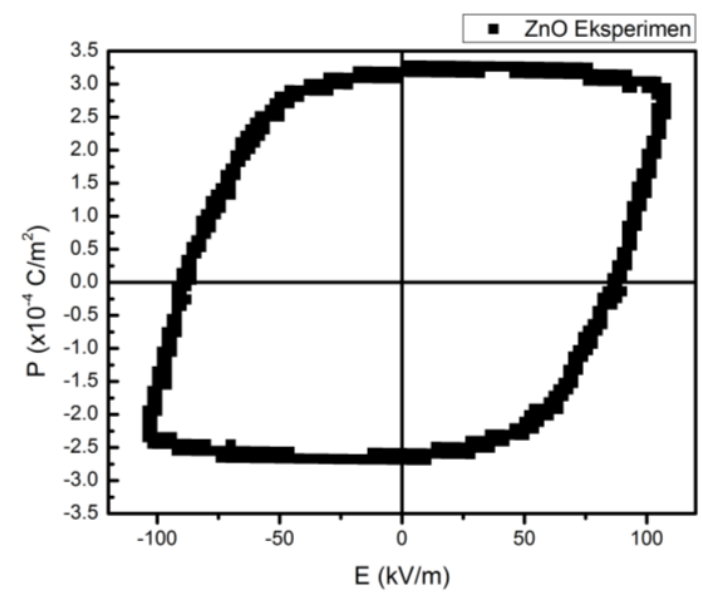

Gambar 3.1. Kurva Histeresis ZnO Eksperimen

Nilai koefisien Landau $\alpha$ dan $\beta$, ditunjukan pada tabel 3.1. Dari tabel tersebut terlihat bahwa nilai $\alpha$ maksimum terdapat pada $\mathrm{ZnO}$ eksperimen begitu juga terjadi pada nilai konstanta Landau $\beta$. Sedangkan nilai konstanta Landau terendah terdapat pada $\mathrm{ZnO}$ doping $\mathrm{Li} 1 \%$

Tabel 3.1. Koefisien Landau dari Zinc Oxide ( $\mathrm{ZnO})$

\begin{tabular}{|c|c|c|}
\hline \multirow{2}{*}{ Materials and Model } & \multicolumn{2}{|c|}{ Result } \\
\cline { 2 - 3 } & $\begin{array}{c}\alpha(\mathrm{V} / \mathrm{m}) \\
\times 10^{7}\end{array}$ & $\begin{array}{c}\beta(\mathrm{m} / \mathrm{F}) \mathrm{x} \\
10^{10}\end{array}$ \\
\hline ZnO aldrich & 67,84 & 5,97 \\
\hline ZnO eksperimen & 78,95 & 9,85 \\
\hline ZnO doping Li 1\% & 37,11 & 1,63 \\
\hline
\end{tabular}

Energi bebas Gibbs dari material Zinc Oxide yang di doping Li 1\% ditunjukan pada gambar 3.2.

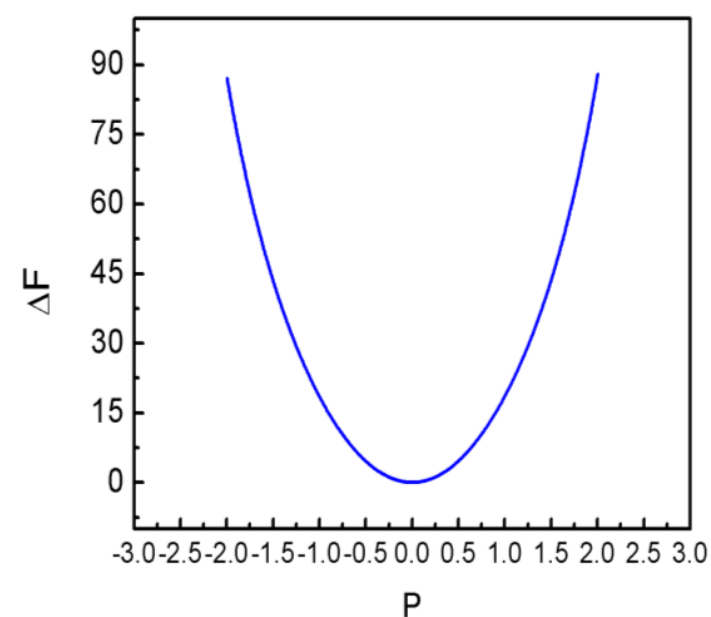

Gambar 3.2. Energi Bebas Gibbs Zinc Oxide (ZnO) doping $\mathrm{Li} 1 \%$

Energi bebas Gibbs dari Zinc Oxide ( $\mathrm{ZnO}$ ) Aldrich, $\mathrm{ZnO}$ eksperimen dan $\mathrm{ZnO}$ doping $\mathrm{Li} 1 \%$ ditunjukan pada gambar 3.3 


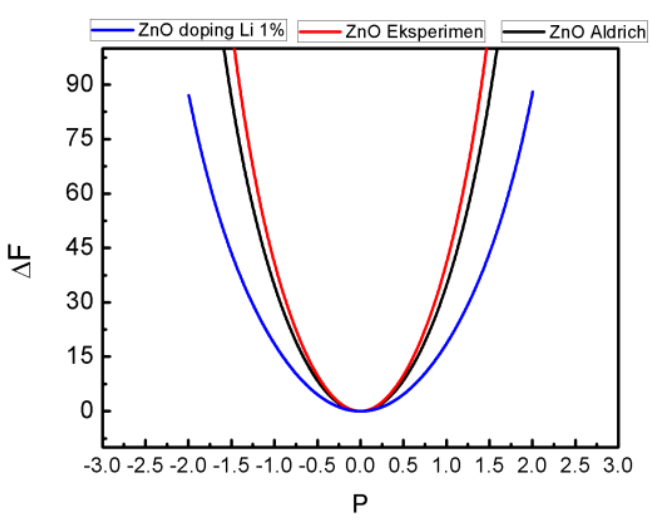

Gambar 3.3. Energi Bebas Gibbs Zinc Oxide (ZnO) Aldrich (Hitam), Eksperimen (Merah) dan doping Li $1 \%$ (biru)

dari hasil perhitungan terlihat bahwa terjadi pergeseran nilai energi bebas Gibbs dari masingmaterial. Energi Bebas Gibbs dari $\mathrm{ZnO}$ eksperimen lebih tinggi dibandingkan $\mathrm{ZnO}$ Aldrich yang artinya bahwa $\mathrm{ZnO}$ Aldrich dalam kondisi lebih stabil dibandingkan dengan $\mathrm{ZnO}$ eksperimen. Hal ini juga terlihat dari koefisien Landau pada $\mathrm{ZnO}$ eksperimen lebih tinggi dibandingkan dengan $\mathrm{ZnO}$ Aldrich. Energi Bebas Gibbs terendah terjadi pada $\mathrm{ZnO}$ doping $\mathrm{Li} 1 \%$, hal ini sesuai dengan nilai dari koefisien Landau. Serta pada $\mathrm{ZnO}$ yang didoping Li maka pada struktur kristal, sebagian atom $\mathrm{Zn}^{2+}$ akan digantikan dengan atom $\mathrm{Li}^{+}$yang mengakibatkan struktur atom $\mathrm{ZnO}$ menjadi lebih stabil dan berada tidak tepat pada pusat struktur hexagonal yang menyebabkan terjadinya dipol pada unit cell. (Bornand dan Mezy, 2013)

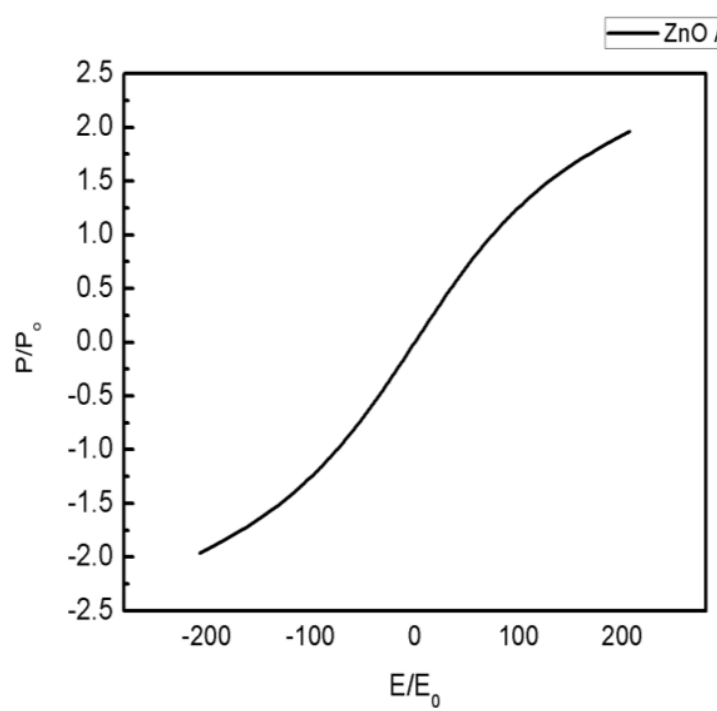

Gambar 3.4 Kurva polarisasi spontan (virgin curve) $\mathrm{ZnO}$ Aldrich

Kurva polarisasi spontan (virgin curve) dari $\mathrm{ZnO}$ Aldrich ditunjukan pada gambar 3.4 dan kurva perbandingan $\mathrm{ZnO}$ Aldrich, $\mathrm{ZnO}$ eksperimen dan $\mathrm{ZnO}$ doping $\mathrm{Li} 1 \%$ ditunjukan pada gambar 3.5.
Dari gambar terlihat bahwa terjadi pergeseran nilai polarisasi spontan (virgin curve) maksimum Terlihat bahwa nilai polarisasi spontan maksimum terjadi pada $\mathrm{ZnO}$ doping $\mathrm{Li} 1 \%$. Hal ini terjadi dikarenakan pada $\mathrm{ZnO}$ doping $\mathrm{Li}$, atom $\mathrm{Zn}^{2+}$ digantikan oleh atom $\mathrm{Li}^{+}$yang menyebabkan struktur atom $\mathrm{ZnO}$ lebih stabil dan nilai total muatan pada satu unit sel serta total polarisasi keseluruhan menjadi lebih besar. (Bornand, 2015, Yadav dkk, 2016)

Dari hasil perhitungan $\mathrm{ZnO}$ eksperimen membutuhkan energi paling besar untuk mencapai polarisasi spontan maksimum. Hal ini terlihat bahwa dibutuhkan medan listrik $250 \mathrm{kV} / \mathrm{m}$ agar mencapai polarisasi maksimum. Hal ini disebabkan oleh struktur kristal dari $\mathrm{ZnO}$ eksperimen maksimum yang tidak tersusun sempurna. Sedangkan $\mathrm{ZnO}$ doping $\mathrm{Li} 1 \%$ membutuhkan energi paling rendah untuk mencapai polarisasi dikarenakan struktur kristal yang lebih stabil dan total muatan pada unit cell tidak sama dengan nol serta posisi atom Li pada strukturnya yang tidak tepat berada di pusat struktur (Bornand, 2015).

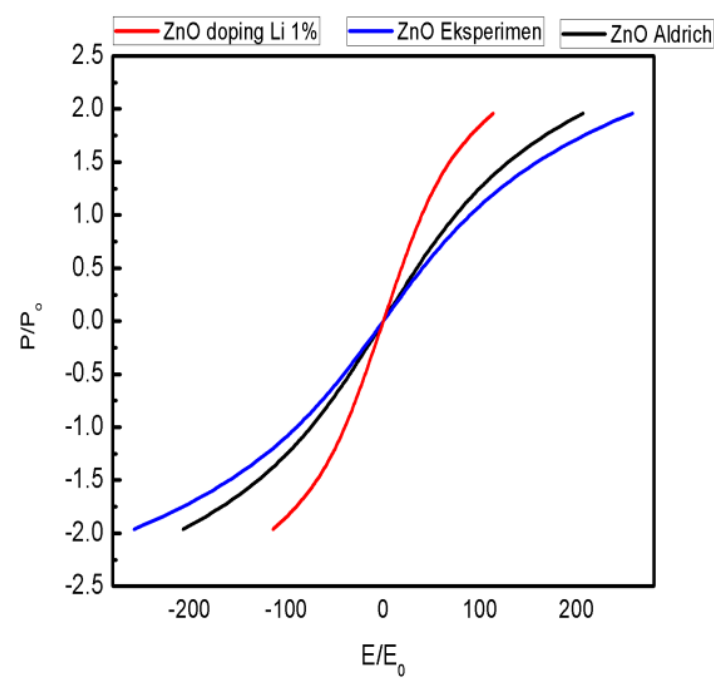

Gambar 3.5. Kurva polarisasi spontan (virgin curve) $\mathrm{ZnO}$ Aldrich (Hitam), $\mathrm{ZnO}$ Eksperimen

(Biru) dan $\mathrm{ZnO}$ doping Li 1\% (merah)

\section{KESIMPULAN}

Dari hasil perhitungan energi bebas Gibbs dan polarisasi spontan (virgin curve) dari material Zinc Oxide ( $\mathrm{ZnO})$. Didapatkan kesimpulan sebagai berikut:

1. Energi bebas Gibbs terendah dan polarisasi spontan maksimum dengan energi terendah didapatkan pada komposisi $\mathrm{ZnO}$ yang didoping Li $1 \%$ 
2. Proses pembuatan material $\mathrm{ZnO}$ memperngaruhi nilai energi Bebas Gibbs dan medan koersif dari material $\mathrm{ZnO}$

3. Doping litium dengan komposisi $1 \%$ pada $\mathrm{ZnO}$ menyebakan material $\mathrm{ZnO}$ menjadi lebih stabil dan polarisasi spontan (virgin curve) dapat dicapai dengan energi lebih rendah.

\section{REFERENSI}

Bornand, V. (2015). Ferroelectric and Dielectric properties in Li-doped $\mathrm{ZnO}$ nanorods. Thin Solid Films. Vol. 571. 152-155

Bornand, V. and Mezy, A. (2013) Morphological and ferroelectric studies of Li-doped $\mathrm{ZnO}$ thin films. Materials Letters. Vol. 107. 357360

Goel, S., Sinha, N., Yadav, H., Godara, S., Joseph, A. J., and Kumar, B. (2017). Ferroelectric Gd-doped $\mathrm{ZnO}$ nanostructure : Enchanced dielectric, ferroelectric and piezoelectric properties. Materials Chemistry and Physics. Vol. 202. 56-64.

Hikam, M and Adnan, S. R. (2014). Intrinsic Hysteresis Loops Calculation of BZT Thin Films. Journal of Physics : Conference Series (JPCS). 495. 012008

Hikam, M and Adnan, S. R. (2014). Intrinsic Ferroelectric Coercive Field Calculation for BZT Films Doped by Indium and Lanthanum. Advanced Materials Research. Vol. 911. pp 256-259

Lines, M. E. \& Glass, A. M. (1977). Principle and Applications of Ferroelectrics and Related Materials. Clarendon Press. Oxford.

Luo, B., Wang X., Tian, E., Song, H., Qu, H., Cai, Z., Li, B., and Li, L. (2018) Mechanism of ferroelectric properties of $(\mathrm{BaCa})(\mathrm{ZrTi}) \mathrm{O}_{3}$ from first principle calculations. Ceramic Internasional. Article in press.

Padurariu, L., Petronela, L., and Mitoseriu, L. (2016). Nonlinear dielectric properties of paraelectric-dielectric composite described by a 3D Finite Element Method based on Landau-Devonshire theory. Acta Materialia. 103. 724-734

Tan, E. K., Osman, J., Tilley, D. R. (2001). Calculation of Intrinsic Hysteresis Loop of Ferroelectric Thin Films. Solid State Communications. 117, 59-64.

Yadav, H., Sinha, N., Goel, S. and Kumar, B. (2016). Eu-doped $\mathrm{ZnO}$ nanoparticles for dielectric, ferroelectric and piezoelectric application. Journal of Alloys and Compound. Vol. 689. 333-341 